Вісник Львівського університету. Серія психологічні науки. 2018. Випуск 3. С. 136-141

Visnyk of the Lviv University. Series Psychological science. Issue 3. P. 136-141

UDC 159.923.2

DOI https://doi.org/10.30970/2522-1876-2018-3-16

\title{
A MODEL OF PSYCHOLOGICAL FACTORS AFFECTING TO ACADEMIC SELF-EFFICACY OF UNIVERSITY STUDENTS
}

\author{
Olena Musakovska \\ Ivan Franko National University of Lviv, \\ 1, Universytetska Str., Lviv, Ukraine, 79000, \\ e-mail: olenkamusakovska@ukr.net
}

\begin{abstract}
The article sets out the results of the empirical research of psychological factors of self-efficacy of learning activity of students of higher education institutions.

In general, 156 persons participated in the research - undergraduate intramural students of the Ivan Franko National University of Lviv aged from 17 to 23 years. In order to identify psychological factors of self-efficacy of students' learning activities, it is used standardized psychological diagnostic methods

(“Academic self-efficacy of students" (I. Sniadanko), Big Five (R. R. MacCrae, P. T. Costa), the method for diagnostics of studying motivation of students of A. Rean, V. Yakunin (modification of N. Ts. Badmaieva), Students' Achievement Motivation in Higher Educational Institutions (S. Pakulina), Personal Maturity Inventory (Yu. Z. Hilbukh) and a questionnaire.

Based on an integrated index the group was divided into three sub-groups according to the level of learning self-efficacy: "highly effective students", "students with medium self-efficacy" and "students with low self-efficacy". The paper studies a correlation of learning self-efficacy with personal characteristics and motivational basis of learning activities of students. Due to Scheffe's single-factor analysis of variance, Pearson correlation coefficient and factor analyses, psychological makers of persons with a high and low level of learning self-efficacy were defined. In particular, students with a high level of learning self-efficacy are characterized as more methodical and persistent in achieving desired goals, more responsible and conscientious and also they have internal achievement motivation. It determines the students' ability to self-regulate the emotional-volitional state and their value attitude to educational activity and professional knowledge as stimulating psychological factors of academic self-efficacy.
\end{abstract}

Key words: self-efficacy, academic self-efficacy of university students, determining factors, self-regulation, achievement motivation.

Problem statement. Students' academic self-efficacy is one of the key factors for the effectiveness of the learning process, recognized as a predictor of academic performance and it contributes to the development of a high level of professional competence. The importance of self-efficacy is increasing during the current educational preparation of qualified specialists in the terms of acquiring the necessary knowledge and improving their professional skills.

Despite a lot of number of publications on self-efficacy beliefs in Western countries over the past decades, the psychological determinants of a high level of self-efficacy in students' educational activities have been scarcely highlighted in Ukrainian psychology.

Recent research and analysis of publications. The study of academic self-efficacy as a kind of personality's efficiency in a particular area of human activity is devoted to the work of such psychologists as D. Shunk, F. Pajares, M. Bong, E.Skaalvik, B. Zimmerman, etc [4-6]. Among the Ukrainian researchers this construct was studied by T. Haltseva and I. Sniadanko [2;3].

The concept of academic self-efficacy is based on the social-cognitive theory of A. Bandura and is interpreted as the individual's confidence in his ability to organize, execute and regulate

(C) Olena Musakovska, 2018 
his or her own educational activity related to solving problems or performing a task at a sufficient level of skill, according to their own capabilities [1].

Academic self-efficacy represents a complex multidimensional phenomenon of self-awareness (cognitive, emotional and behavioral level) which is defined as a motivated self-confidence with emotionally stable behavior during stressful learning situations and it is reflected in the implementation of a successful system of learning actions.

These beliefs begin to form in early childhood under the influence of the immediate environment, develop its main components in the younger school-age, and improve in the following age periods.

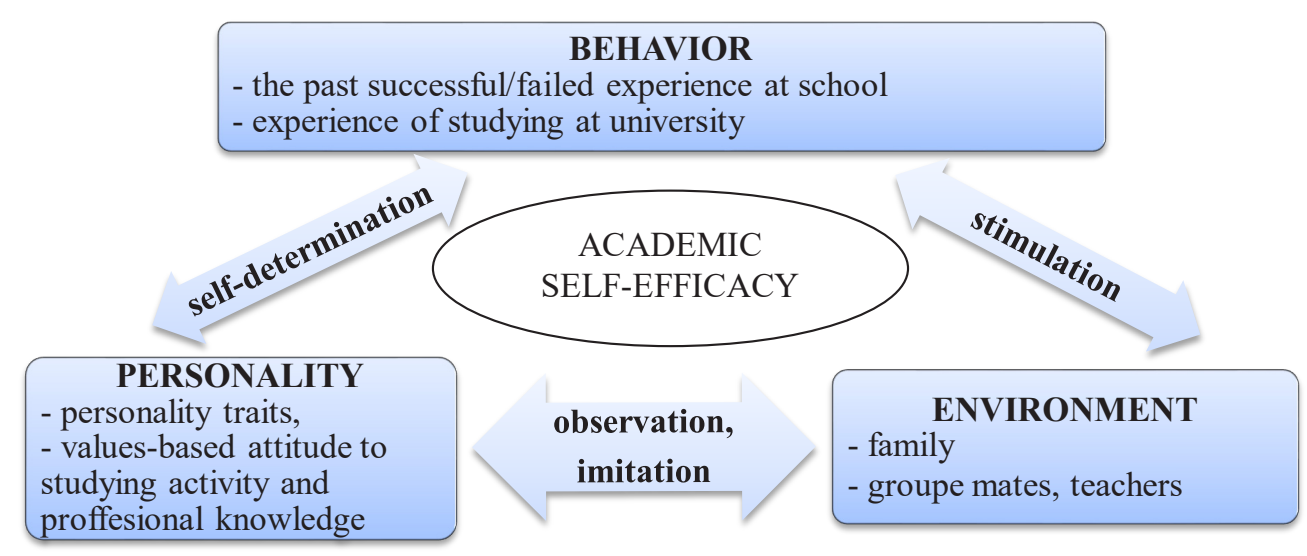

Fig. 1. Theoretical model of mutual determinism of factors and mechanisms of students' academic self-efficacy

The level of students' academic self-efficacy is determined as a result of a cognitive interpretation of the past school performance and the current university experience of learning, observing the activities of successful reference persons (other students), self-analysis of their own physical and emotional state in educational activities and verbal supporting by credible persons: relatives (parents, siblings), teachers, classmates and group mates.

The psychological factors of academic self-efficacy are aggregated into two blocks: «personality traits» (a positive self-attitude, an ability to self-regulate behavior, a high emotional stability) and "valuable attitude to learning activities and professional knowledge" as a motivational basis for their cognitive activity.

The purpose of this study was to study psychological factors of academic self-efficacy of university students. Specifically, we tested a theoretical model positing that (a) such volitional qualities as responsibility, persistence, organization and emotional stability, in particular low level of anxiety, less tension, high self-sufficiency determine the level of self-efficacy in the student's educational activity and that (b) self-efficacy of students is affected by their value attitude to the learning process and professional knowledge, in particular the presence of stable cognitive interest (see Figure 1).

Main part of the research. Empirical research included 156 students of the Ivan Franko National University of Lviv, 14 males and 142 females aged from 17 to 27 years old; 52 of them first- and second-year students, 72 - third- and fourth-year students and 32 - master's students; 136 studied social and humanitarian sciences, 20 - natural sciences. 
The Method «Academic self-efficacy of students» (I. Sniadanko) is designed to determine the level of self-efficacy in learning activities. The Big Five personality test measures personality traits defined as openness to experience, conscientiousness, extraversion, agreeableness, and neuroticism. The questionnaire-test of personal maturity by Yu. Hilbukh is used to determine the level of students' personal maturity. The method 'Students' Achievement Motivation in Higher Educational Institutions" (S. Pakulina) is applied to determine the value of success as internal and external motives in the structure of achievement motivation of studying. In addition to that, the method of diagnostics of studying motivation of students (A. Rean, V. Yakunin) is used. A questionnaire was developed to assess socio-demographic characteristics of students, their family structure and social capital, features of learning experience at school and university.

To verify statistical validity of the data obtained the following statistical and mathematical methods were used: cluster analysis, Scheffe's post hoc test, correlation (Pearson $r$ with $p<0,05$ ), factor, discriminant and multiple regression analysis.

With the help of hierarchical cluster analysis on the sample of 156 students three groups with high $(\mathrm{N}=50)$, medium $(\mathrm{N}=64)$ and low $(\mathrm{N}=42)$ academic self-efficacy were revealed $(\mathrm{M} 1=119,6 ; \mathrm{M} 2=91,8 ; \mathrm{M} 3=68,7, \mathrm{p}<0,05)$.

As can be seen in the Table 1 , in the group of highly effective students, a direct correlation between the indicators of self-efficacy and self-control $(r=0,316 ; p \leq 0,05)$ was determined. Also, the academic self-efficacy in this group of students correlates with the motivation to achieve success as a result of their own activities $(\mathrm{r}=0,455 ; \mathrm{p} \leq 0 ; 01)$.

Table 1

The relationships between academic self-efficacy in different subgroups and others indicators

\begin{tabular}{|c|c|c|c|c|}
\hline \multicolumn{2}{|r|}{ Scale } & High & Medium & Low \\
\hline \multirow{3}{*}{ Personalty traits } & Self-control-impulsiveness & 0,316 & ----------- & ----------- \\
\hline & Persistence-weakness & ------------ & ----------- & 0,389 \\
\hline & Searching impression-its avoiding & ------------ & ------------ & $-0,337$ \\
\hline \multirow{7}{*}{ Motives of studying } & Success as a result of own activities & $0,455^{*}$ & 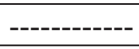 & 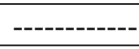 \\
\hline & Success-vocation & ----------- & - ---------- & $-0,309$ \\
\hline & Internalization of success & 0,352 & ------------ & |----------- \\
\hline & Success-recognition & ----------- & ----------- & 0,309 \\
\hline & Success-authority & ------------ & ------------ & 0,390 \\
\hline & Professional motives & ------------ & $0,455^{*}$ & 0,335 \\
\hline & Knowledge motives for studying & ---------- & $0,359 *$ & ---------- \\
\hline
\end{tabular}

* With $\mathrm{p}<0,01$

The factor structure of empirical data for students with higher level of academic selfefficacy includes on six factors: significant motives for learning activities, a personality maturity, a social orientation of the individual, an internal locus of academic self-efficacy, motives for successful professional activity and academic performance.

Consequently, students with a high level of academic self-efficacy have more positive self-assessment themselves and higher academic achievements in university studies; are characterized by confidence and persistent, a higher level of self-control: the ability of volitional regulation of their own behavior, characterized by greater emotional stability and social orientation. This group is capable of directing activities to meaningful life goals, seeking self-realization. 
They have a strong cognitive interest, seek to become highly skilled specialists. These students are internally more motivated by the achievement of professional skills in the education process that they evaluate in the category of the significance of their own activities, especially, the efforts they make to achieve a positive result.

Additionally, in the group of low-efficacy students Table 1 indicates an inverse correlation between academic self-efficacy and perceived success as a vocation $(r=-0.309 ; p \leq 0.05)$; direct relationships with such success categories as recognition $(r=0.309 ; p \leq 0,05)$ and authority $(\mathrm{r}=0,390 ; \mathrm{p} \leq 0,05)$. The factor structure for the subgroup with lower academic self-efficacy consists on such six factors as a lack of studying motivation, an infantilism of personality, an impulsiveness and internal orientation of the individual, a lack of volitional regulation in educational activities, a social passivity and an external locus of academic self-efficacy.

Thus, students with lower level of academic self-efficacy are more infantile, closed, sufficiently impulsive, have a lack of persistence, with a tendency to avoid difficult situations of going beyond their comfort zone. Also this group is less motivated to succeed, while has a need to social reinforcement and support for their effectiveness.

Thus, the regression model explains 55\% dispersion (determination coefficient $\mathrm{R} 2=0,549)$. The coefficient of multiple correlation $(\mathrm{R}=0,7405)$, which determines the degree of dependence between psychological parameters and the level of academic self-efficacy, is statistically significant. According to the regression model, the psychological factors that determine the level of academic self-efficacy are the most significant (based on the values of the regression coefficients), the contribution of such components is «knowledge motives for studying» (beta $=0,424)$, «professional motives» (beta $=0,301)$, «emotional stability» (beta $=0,301)$, «self-control» (beta $=-0,273)$, «exteriorization of success» (beta $=0,221)$, «motives for avoiding» (beta $=-0,213)$, «I-concept» (beta $=0,198)$ and «communicative motives» (beta $=-0,188)$.

Based on these results, an empirical model of psychological factors of students' academic self-efficacy was constructed (Figure 2).

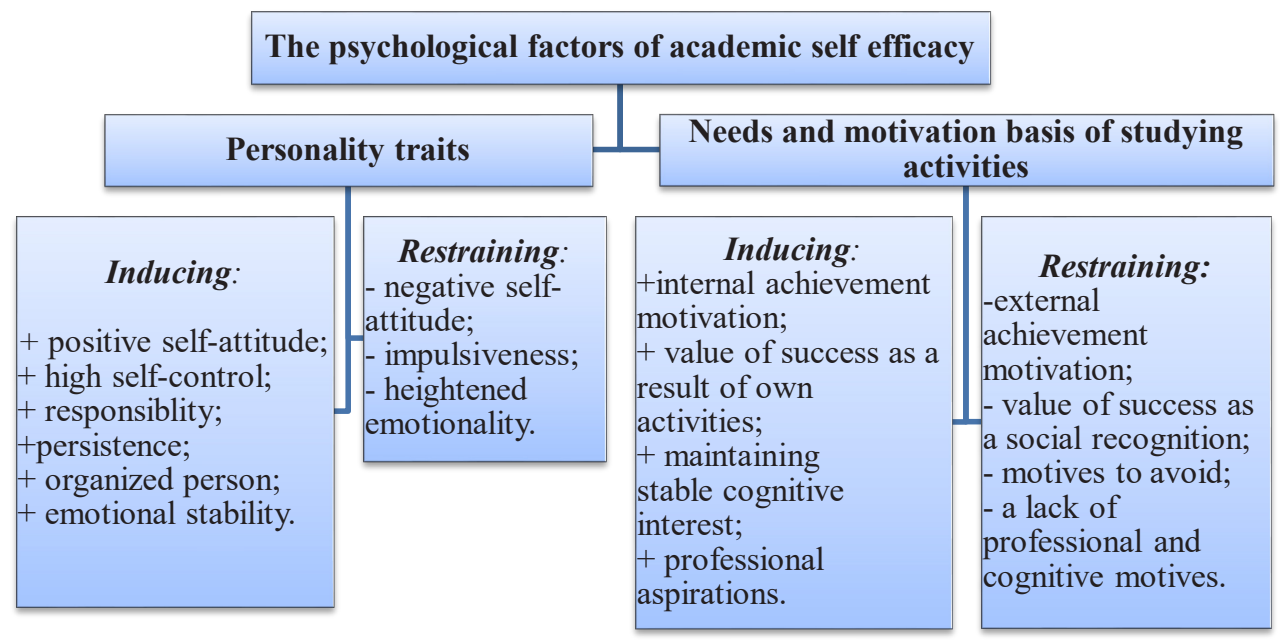

Fig. 2. Empirical model of psychological factors of students' academic self-efficacy

According to the personality traits, the self-attitude and self-regulation of students are shown as the indicating (positive self-attitude, high self-control, responsibility, persistence, organized 
person and emotional stability) and restraining factors (negative self-attitude, impulsiveness and heightened emotionality). Emotional and behavior control refers to the ability of students to manage emotional reactions in stressful learning situations. There is a mobilization of internal human resources, and the attention of students is aimed at achieving the set educational goals.

The domination of professional motivation in learning activities indicates an individual's interest in the chosen profession and the desire of students to become highly skilled. Therefore, it should be emphasized that the existing internal motives stimulate the perfection of professional skills, to improve the individual knowledge and abilities of the student, contributing to academic self-efficacy. In this case, the student's cognitive activity is persistent expanded and concerns the acquisition of professional knowledge. Thus, the motivational basis for the student's learning process is the realized cognitive needs such as cognitive interest and professional aspirations that contribute to the cognitive activity of the individual.

Conclusions and prospects for further research. The most significant factors of the growth of the level of academic self-efficacy is the contribution of value-semantic aspects of the motivation of educational activities (the values of internalized success, educational and professional motivation) and personal qualities (emotional stability, self-control).

Further research of these issues can be related to the development of efficiency in educational activities in the context of the formation of professional identity, compare to peculiarities of the development academic and professional self-efficacy of future specialists.

\title{
References
}

1. Бандура А. Теория социального научения. Санкт-Петербург: Евразия, 2000. 320 с.

2. Гальцева Т.О. Вплив соціально-психологічних чинників на становлення навчальної самоефективності студентів. Науковий вісник Херсонського держаного університету. Серія: Психологічні науки. 2017. Вип. 2. С. 74-79.

3. Сняданко I.I. Діагностика рівня навчальної самоефективності студентів. Практична психологія та соціальна робота: науково-практичний та освітньо-методичний журнал. 2014. № 1. C. 45-51.

4. Bong M., Skaalvik E. M. Academic self-concept and self-efficacy: how different are they really? Educational psychology review. 2003. Vol. 15, No. 1. P. 1-40.

5. Schunk D. H., Pajares F. The Development of academic self-efficacy. Development of achievement motivation. San Diego: Academic Press, 2001. 27 p.

6. Zimmerman B. J. Self-efficacy: An essential motive to learn. Contemporary Educational Psychology. 2000. Vol. 25. P. 82-91.

\section{ЕМПІРИЧНА МОДЕЛЬ ПСИХОЛОГІЧНИХ ЧИННИКІВ НАВЧАЛЬНОЇ САМОЕФЕКТИВНОСТІ СТУДЕНТІВ}

\author{
Олена Мусаковська \\ Львівський національний університет імені Івана Франка, \\ вул. Університетська, 1, м. Львів, Украӥна, 79000, \\ e-mail: olenkamusakovska@ukr.net
}

У статті представлено результати емпіричного дослідження психологічних чинників самоефективності навчальної діяльності студентів вищих навчальних закладів.

Загалом у дослідженні взяли участь 156 осіб, студенти I-VI курсів денної форми навчання Львівського національного університету імені Івана Франка, віком від 17 до 27 років. Із метою емпіричного визначення психологічних чинників самоефективності навчальної діяльності студентів 
використано стандартизовані психодіагностичні методики (методика «Навчальна самоефективність студента» I.I. Сняданко, п’ятифакторний особистісний опитувальник Р. Р. Маккрае, П. Т. Коста, методика для діагностики навчальної мотивації студентів А.А. Реана, В.А. Якуніна (модифікація Н. Ц. Бадмаєвої), «Мотивація досягнення успіху студентів у ВНЗ» С.А. Пакуліної, тест-опитувальник особистісної зрілості Ю.З. Гільбуха) та анкету.

На основі комплексного показника «Навчальна само ефективність» досліджувану групу було поділено на три підгрупи за рівнем прояву навчальної само ефективності: «високоефективні», «помірно ефективні», «низькоефективні» студенти. Досліджено взаємозв'язок навчальної самоефективності з особистісними характеристиками та мотиваційною основою навчальної діяльності студентської молоді. В результаті однофакторного дисперсійного аналізу Шеффе, кореляційного (лінійна кореляція за Пірсоном) та факторного аналізів визначені психологічні особливості осіб із високим та низьким рівнем навчальної самоефективності. Зокрема, студенти з високим рівнем навчальної самоефективності характеризуються як більш методичні та наполегливі в досягненні поставлених цілей, більш відповідальні та сумлінні, також їм притаманна внутрішня мотивація досягнення. Виділено здатність студентів до саморегуляції емоційно-вольового стану та їхнє ціннісне ставлення до навчальної діяльності та професійного знання як стимулюючі психологічні чинники навчальної самоефективності.

Ключові слова: самоефективність особистості, навчальна самоефективність студента, детермінанти, саморегуляція, мотивація досягнення. 